\title{
Pengembangan Media Pop Up Book pada Pembelajaran Tema VI Cita-Citaku Subtema 1 Aku dan Cita-Citaku
}

\author{
Feni Fadzilah1*, Ibnu Fatkhu Royana², Diana Endah Handayani3 \\ 123 Program Studi Pendidikan Guru Sekolah Dasar FIP, Universitas PGRI Semarang, Indonesia
}

\begin{abstract}
Abstrak
Latar belakang yang mendorong penelitian ini adalah masih kurangnya penggunaan media dalam membantu proses pembelajaran, media yang digunakan berupa gambar biasa. Rumusan masalah dalam penelitian ini adalah "Apakah pengembangan media pop up book diterima sebagai media pembelajaran pada tema VI Cita-citaku Subtema 1 Aku dan Cita-citaku Kelas IV SD Negeri Wonokerto 01?'. Jenis penelitian ini adalah penelitian dan pengembangan (research and development). Penelitian ini dilakukan di SDN Wonkerto 01 Batang pada kelas IV. Hasil penilaian rata-rata validasi ahli materi dan ahli media pembelajaran adalah 94,21\% dengan kategori "Baik Sekali". Hasil perhitungan angket respon guru adalah 92,85\% dengan kategori "Baik Sekali". Hasil perhitungan angket respon siswa adalah 90\% dengan kategori "Baik Sekali". Hasil perhitungan angket keberterimaan media adalah 90\%. Kesimpulannya bahwa pengembangan media POP UP BOOK pada Tema VI Cita-citaku Subtema 1 Aku dan Cita-citaku Pembelajaran 2 dapat diterima sebagai media pembelajaran.
\end{abstract}

\section{Keywords:}

Pengembangan, $P O P$ UP BOOK, Tematik

\section{PENDAHULUAN}

Pendidikan merupakan sarana mentransfer ilmu antara pendidik dan peserta didik dengan tujuan untuk mendewasakan diri manusia melalui proses pembelajaran terencana. Pendidikan sangat penting bagi kehidupan manusia, karena dianggap mampu mengembangkan potensi-potensi yang dimiliki setiap individu. Menurut Undang-Undang Republik Indonesia No. 20 tahun 2003 tentang Sistem Pendidikan Nasional, pendidikan adalah usaha sadar dan terencana untuk mewujudkan suasana belajar dan proses pembelajaran agar peserta didik mengembangkan potensi dirinya untuk memiliki kekuatan spiritual keagamaan, pengendalian diri, kepribadian, kecerdasan, akhlak mulia, serta keterampilan yang diperlukan dirinya, masyarakat, bangsa, dan negara.

Pembelajaran yang efektif, menarik, kondusif dilaksanakan untuk mencapai tujuan pendidikan. Pendidik diminta untuk mengembangkan potensi yang dimiliki untuk diberikan ke peserta didiknya agar generasi penerus bangsa bisa mengikuti perkembangan zaman. Menurut Hartono (2013:8), seorang guru membutuhkan keterampilan mengajar yang lebih dibandingkan dengan yang bukan guru. Guru harus mempunyai wawasan tinggi mengenai informasi terkini, strategi pembelajaran, teknologi, dan media pembelajaran. Selain mengembangkan ketrampilan ilmu, pendidik juga harus memperhatikan karakteristik peserta didik. Dengan memperhatikan karakteristik setiap peserta didik, pendidik mampu untuk mengendalikan kegiatan pembelajaran. Terjadi sikap timbal balik antara pendidik dan peserta didik dalam pembelajaran sehingga kebutuhan pendidik dan peserta didik terpenuhi dengan seimbang.

\footnotetext{
* Corresponding author. 
Kurikulum yang berlaku di sekolah-sekolah dalam pendidikan Indonesia saat ini adalah Kurikulum 2013 dalam pembelajaran tematik terpadu. Menurut Subroto dalam Kadir dan Asrohah (2014:6) dalam definisi yang lebih operasional, bahwa pembelajaran tematik adalah pembelajaran yang diawali dengan suatu pokok bahasan atau tema tertentu yang dikaitkan dengan pokok bahasan lain, konsep tertentu dikaitkan dengan konsep lain, yang dilakukan secara spontan atau direncanakan, baik dalam satu bidang studi atau lebih, dan dengan beragam pengalaman belajar siswa, maka pembelajaran menjadi lebih bermakna.

Menurut Wahyuni (2016) pembelajaran tematik merupakan pembelajaran yang didasarkan dari sebuah tema yang digunakan untuk mengaitkan beberapa konsep mata pelajaran, sehingga anak akan lebih mudah memahami sebuah konsep, karena hanya berdasarkan dari satu tema untuk beberapa pelajaran yang diajarkan. Menurut Haji (2015) Pembelajaran tematik adalah pembelajaran yang dirancang berdasarkan tema-tema tertentu, dalam pembelajaran lain pembelajaran tematik adalah pembelajaran terpadu yang menggunakan tema untuk mengaitkan beberapa mata pelajaran sehingga dapat memberikan pengalaman bermakna kepada peserta didik. Pembelajaran tematik menawarkan berbagai macam model-model pembelajaran sehingga aktivitas pembelajaran menjadi lebih menyenangkan dan berfikir lebih kreatif. Pembelajaran tematik dalam kurikulum 2013 berpusat pada siswa, jadi guru sebagai sumber informasi namun siswa diminta untuk berfikir kreatif, mandiri dan aktif. Namun dalam pembelajaran tematik guru harus membuat pembelajaran menjadi menyenangkan, menjelaskan materi dengan baik, memotivasi siswa untuk terus belajar dan membuat media pembelajaran yang baik agar mempermudah siswa dalam belajar.

Menurut Asmara (2015) Proses pembelajaran merupakan keterpaduan proses mengajar dan belajar. Proses mengajar merupakan penyampaian informasi dari fasilitator pengetahuan kepada akseptornya. Selain sebagai penyampai informasi kepada siswa, fasilitator pembelajaran juga sebagai pengatur proses pembelajaran dan lingkungan di dalam kelas.Menurut Sanaky (2013:4) media pembelajaran adalah sarana atau alat bantu pendidikan yang dapat digunakan sebagai perantara dalam proses pembelajaran untuk mempertinggi efektifitas dan efisiensi dalam mencapai tujuan pengajaran. Kesuksesan kegiatan pembelajaran tidak terlepas dari kreativitas seorang guru dalam menciptakan kegiatan pembelajaran dan dalam menggunakan media pembelajaran. Media pembelajaran sangat penting dalam pembelajaran karena selain dapat membantu guru dalam menyampaikan materi, media juga dapat memancing rasa penasaran siswa. Siswa lebih giat dalam mengikuti pembelajaran dan berfikir kreatif. Menurut Sholikhah (2017) Pop Up Book merupakan buku yang menampilkan halaman-halaman buku yang di dalamnya terdapat lipatan gambar yang dipotong yang membentuk lapisan tiga dimensi yang dapat pula digerakkan sehingga tidak membosankan pembacanya. Menurut Azizan (2018) Proses pengembangan Media Pop Up Book ada tujuh tahapan yang dimulai dari analisis kebutuhan pebelajar dan diakhiri dengan naskah siap produksi. Tahap pertama, dilakukan penganalisisan wawancara secara tidak terstruktur dilanjut pemberian angket kebutuhan pebelajar. Kedua, perumusan tujuan instruksional sesuai dengan teori sadiman. Ketiga, perumusan butir-butir materi. Keempat, perumusan alat pengukur keberhasilan berupa perancangan pedoman penilaian penskoran. Kelima, penulisan naskah media melalui tiga tahapan yaitu, praproduksi, produksi, dan pascaproduksi. Keenam, melakukan tes dan revisi untuk mengetahui kualitas media pop up book yang dikembangkan dan sekaligus memeroleh kritik dan saran dari validator ahli. Ketujuh, naskah siap produksi dilanjut dengan membuat media sesuai tema yang dipilih dan cocok digunakan untuk menunjang kebutuhan pebelajar. Menurut Masturah (2018) Pop-Up Book dapat di desain sesuai dengan kebutuhan materi yang harus diajarkan oleh siswa dan tentunya dengan memperhatikan bagaimana langkah-langkah pembelajaran siswa tersebut. Keunggulan dari PopUp Book yaitu dapat memvisualisasikan gambar menjadi lebih menarik. Pop-Up Book dapat digunakan sebagai bahan ajar siswa secara individu maupun secara berkelompok dan Pop-Up Book bersifat praktis dan dapat menambah semangat serta minat siswa dalam belajar karena dapat memvisualisasikan konsep dalam pelajaran kedalam bentuk gambar 3 dimensi. Tampilan Pop-Up Book menjadi salah satu keunggulan karena tampilannya yang unik dan berbeda dengan media pembelajaran berbentuk dua dimensi yang lainnya. Pop-Up Book ini memiliki dimensi gambar yang dapat timbul ketika halaman dibuka.

Berdasarkan hasil observasi di lapangan pada siswa SD Negeri Wonokerto 01 dan hasil wawancara dengan guru kelas IV SD Negeri Wonokerto 01 oleh Ibu Umi Khamidah, S.Pd, mengatakan bahwa pembelajaran pada kelas IV sudah berjalan namun siswa dalam mengikuti pembelajaran belum bersemangat. Hal ini dilihat dari media yang digunakan guru masih sederhana dan seadanya. Kadang guru membawa sendiri dari rumah karena kurangnya sarana dan prasaran yang ada disekolah. Media yang digunakan dalam pembelajaran kurikulum 2013 belum beragam, karena guru harus menyesuaikan dengan tema-tema yang ada dalam kurikulum 2013. Dalam pembelajaran tematik khususnya Tema VI Cita-citaku Subtema 1 Aku dan Cita-citaku guru masih menggunakan media berupa gambar dan 
menggambar hewan, tangga nada di papan tulis. Dalam tema tersebut cenderung memerlukan alat bantu mengajar atau media pembelajaran supaya pembelajaran bisa lebih mudah untuk dipahami dan siswa berfikir secara mandiri. Guru belum mengembangkan media pembelajaran menjadi lebih menarik sehingga siswa belum mempunyai minat dalam belajar. Dari hasil analisis kebutuhan siswa peneliti memberikan pilihan terhadap siswa tentang media pembelajaran yang akan digunakan yaitu 1) Media pembelajaran berupa buku tema, 2) Media pembelajaran berupa gambar yang diprint, 3) Media pembelajaran berupa buku yang berwarna yang dapat ditarik dan gambar dapat muncul atau pop up book. Dari hasil analisis dapat diketahui bahwa siswa lebih menyukai media yang mempunyai banyak warna dan menarik. Dalam hasil observasi angket kebutuhan siswa diketahui bahwa media pembelajaran yang diperlukan oleh siswa merupakan media pembelajaran yang dapat menggugah semangat siswa untuk belajar dan memperhatikan guru. Dari hasil analisis kebutuhan guru dapat disimpulkan bahwa guru memerlukan alat bantu mengajar, dan pembelajaran yang kreatif. Sebelunya peneliti juga melakukan observasi mengenai pop up yang dikembangkan. Peneliti melakukan observasi pop up book yang dibuat oleh saudari Firliani Utari, didalam buku pop up tersebut yang diberi nama POP UP BOOK Pendidikan Kelas 1 SD terdapat beberapa halaman yang menampilkan gambar yang dapat muncul ditengah, gambar tersebut merupakan gambar orang yang sedang menyiram tanaman, gambar seorang ibu dan anak yang sedang melakukan percakapan dan gambar juga terdapat gambar pohon, terdapat penjelasan materi yang berada di setiap halaman yang diletakkan didekat gambar yang muncul. Peneliti juga mengembangkan dari buku siswa menjadi pop up book.

Hasil belajar siswa juga masih banyak yang belum memenuhi KKM. Rata-rata hanya terdapat 20 siswa dari 38 siswa atau sekitar 50\% yang dapat mendapatkan nilai kurang dari KKM yaitu 67. Salah satu faktor penyebab masih banyaknya siswa yang belum memenuhi KKM adalah dengan pembelajaran yang masih monoton, belum merangsang siswa untuk berfikir secara kreatif dan kritis. Untuk mengatasi permasalahan tersebut, penulis melakukan penelitian dengan megembangkan buku tema untuk keperluan siswa dalam pembelajaran yang berbentuk media pop up book untuk menarik siswa dalam belajar.

Berdasarkan hasil wawancara, survei data KKM, angket kebutuhan siswa dan guru di SD Negeri Wonokerto 01 dan penelitian yang relevan yang telah dilakukan oleh peneliti lainnya dengan menggunakan media pop up book yang mempunyai bermacam-macam gambar, warna-warna yang menarik, dan mudah digunakan, peneliti bermaksud mengembangkan media pembelajaran tematik untuk membuat siswa lebih semangat dalam belajar, berfikir secara kritis, kreatif dan hasil belajar menjadi lebih maksimal melalui pop up book. Dengan demikian, peneliti melakukan penelitian dengan judul "Pengembangan Media POP UP BOOK pada Pembelajaran Tema VI Cita-citaku Subema I Aku dan Citacitaku Kelas IV SD Negeri Wonokerto 01 Batang".

\section{METODE PENELITIAN}

Jenis penelitian yang diajukan oleh penulis adalah penelitian dan pengembangan (Research and Development). Sugiyono (2017:407) metode penelitian dan pengembangan atau dalam bahasa Inggrisnya Research and Development adalah metode penelitian yang digunakan untuk menghasilkan produk tertentu, dan menguji keefektifan produk tersebut. Design Research dapat dikatakan sebagai suatu metode penelitian yang sesuai untuk mengembangkan solusi (penyelesaian) berdasarkan penelitian untuk suatu masalah yang kompleks dalam praktik pendidikan atau untuk mengembangakan atau memvalidasi suatu teori tentang proses belajar, lingkungan belajar, dan sejenisnya. Jadi metode penelitian dan pengembangan merupakan suatu metode yang digunakan untuk mengembangkan suatu produk baru agar lebih sempurna lagi.

Dalam penelitian pengembangan ini, peneliti mengacu pada model penelitian Borg and Gall dalam Sukmadinata (2013: 169) prosedur ini memiliki 10 langkah penelitian dan pengembangan. Namun pada penelitian dan pengembangan hanya menggunakan sampai langkah ke lima dikarenakan keputusan dari program studi Pendidikan Guru Sekolah Dasar untuk Strata (S1). Langkah desain Borg and Gall dijelaskan melalui tabel berikut:

Tabel 1. Langkah Pengembangan

\begin{tabular}{lll}
\hline \multicolumn{1}{c}{ Langkah Model } & \multicolumn{1}{c}{ Kegiatan Penelitian } & \multicolumn{1}{c}{ Langkah R\&D } \\
\hline $\begin{array}{l}\text { Pengumpulan data } \\
\begin{array}{l}\text { Perencanaan (pemecahan } \\
\text { masalah) }\end{array}\end{array}$ & $\begin{array}{l}\text { Analisis kinerja dan kebutuhan untuk } \\
\text { menentukan solusi yang tepat } \\
\text { Menentukan kompetensi khusus, } \\
\text { metode, bahan ajar dan strategi }\end{array}$ & $\begin{array}{l}\text { Langkah ke 1 R\&D studi } \\
\text { lapangan dan studi literatur }\end{array}$ \\
\hline
\end{tabular}




\begin{tabular}{|c|c|c|}
\hline & pembelajaran & \\
\hline Pengembangan draft & $\begin{array}{l}\text { Memproduksi bahan ajar yang akan } \\
\text { digunakan }\end{array}$ & $\begin{array}{l}\text { Langkah ke } 3 \text { pengembangan } \\
\text { produk berupa bahan ajar, } \\
\text { strategi dan media }\end{array}$ \\
\hline Uji coba & $\begin{array}{l}\text { Melaksanakan pelatihan dan } \\
\text { menerapkan desain }\end{array}$ & $\begin{array}{l}\text { Langkah ke } 4 \text { R\&D uji coba } \\
\text { terbatas dan uji coba lapangan }\end{array}$ \\
\hline Revisi & $\begin{array}{l}\text { Melakukan evaluasi program pelatihn } \\
\text { dan evaluasi hasil belajar }\end{array}$ & $\begin{array}{l}\text { Langkah ke } 5 \text { evaluasi dan revisi } \\
\text { produk }\end{array}$ \\
\hline
\end{tabular}

Dalam hal ini penulis memilih jenis penelitian berupa penelitian dan pengembangan (Research and Development) karena penulis mengembangkan produk berupa media pembelajaran. Media pembelajaran ini dikembangkan dengan inovasi yang baru tentunya melalui tahap pengujian terlebih dahulu.

Subyek penelitian adalah seluruh siswa kelas IV SDN Wonokerto 01 Batang. Analisis data yang digunakan dalam penelitian ini yaitu analisis data kualitatif dan analisis data kuantitatif. Data kualitatif dalam penelitian ini yaitu berupa komentar dan saran perbaikan dari ahli media dan ahli materi pembelajaran. Data kuantitatif dalam penelitian ini berupa skor penilaian ahli media, ahli materi, respon guru, siswa dan angket keberterimaan media. Kedua data tersebut didapat dari pengisian angket. Data yang sudah terkumpul dianalisis dengan cara menghitung skor yang diperoleh. Analisis skor yang digunakan yaitu analisis deskriptif yang dianalisis menggunakan langkah-langkah sebagai berikut:

\section{A. Penilaian angket respon guru}

Menganalisis dari lembar angket respon guru dengan skala Likert berbentuk Checklist (?) dengan langkah sebagai berikut: (a) Peneliti menghitung skorsing setiap jawaban; (b) Menghitung jumlah skor yang diperoleh dari penelitian; (c) Menjumlahkan skor ideal yang diperoleh untuk seluruh item; (d) Membagi jumlah skor total dengan skor ideal; (e) Kemudian dikali 100\%.

$$
\text { presentase }=\frac{\text { skor } \text { total }}{\text { skor ideal }} \times 100 \%
$$

Dari presentase yang telah diperoleh kemudian ditransformasikan kedalam kalimat yang bersifat kuantitatif. Untuk menentukan kriteria dikemukakan Arikunto (2010: 269):

Tabel 2. Kriteria Skor Dikemukakan Arikunto

\begin{tabular}{ccc}
\hline No. & Interval ( $\%$ ) & Kriteria \\
\hline 1 & $81-100$ & Baik Sekali \\
2 & $61-80$ & Baik \\
3 & $41-60$ & Cukup \\
4 & $21-40$ & Kurang \\
5 & $0-20$ & Kurang Sekali \\
\hline
\end{tabular}

Berdasarkan tabel 2 dijelaskan bahwa dalam menghitung penilaian angket respon guru diperlukan rumus presentase yang kemudian dapat dilihat nilainya melalui interval dan kriteria kualitatif. Apakah media yang dibuat peneliti sangat tidak layak atau sangat layak untuk digunakan.

B. Penilaian angket respon siswa dan keberterimaan media

Hasil penilaian respon siswa dan keberterimaan media terhadap media pembelajaran Pop Up Book untuk menganalisis data dari lembar angket tanggapan siswa dan keberterimaan media dengan skala Guttman yang berupa "Ya-Tidak" diubah menjadi angka, dapat dilihat pada Tabel 3.

Tabel 3. Penskoran Angket Tanggapan Siswa

\begin{tabular}{cc}
\hline Respon Siswa & Skor \\
\hline Ya & 1 \\
Tidak & 0 \\
\hline
\end{tabular}


Data kuantitatif yang terkumpul selanjutnya dianalisis dengan skala likert. Persentase tersebut menunjukkan tingkat keberterimaan media pembelajaran Pop Up Book berdasarkan penilaian respon siswa dan keberterimaan media kelas IV SDN Wonokerto 01 Batang.

Berdasarkan penilaian kedua angket tersebut peneliti dikatakan berhasil apabila sesuai dengan indikator yang diharapkan. Dapat dikatakan diterima apabila presentase dari hasil ahli media dan ahli materi, angket respon guru, siswa dan keberterimaan media berada pada rentang 61-80\% dengan kriteria "baik".

\section{ANALISIS DAN PEMBAHASAN}

Media pembelajaran Pop Up Book dikembangkan berdasarkan penelitian dan pengembangan (research and development). Penelitian ini menggunakan desain pengembangan Borg and Gall .

A. Pengumpulan data

Pada tahap ini mengumpulkan data atau permasalahan yang ada, ditemukan permasalahan dalam pembelajaran di kelas IV. Permasalahan tersebut adalah siswa kurang aktif dalam bertanya, serta belum tersedianya media pembelajaran yang menarik. Karena guru tidak menggunakan media pembelajaran yang menarik siswa kurang tertarik untuk mengikuti pelajaran sehingga siswa mengalami kesulitan untuk memahami materi.

\section{B. Perencanaan}

Berdasarkan studi pendahuluan yang telah dilakukan, maka mengembangkan media pembelajaran yang dapat menarik perhatian siswa untuk belajar. Media yang dikembangkan adalah media Pop Up Book. Media ini terbuat dari kertas Ivory yang di dalamnya terdapat gambar dan warna yang menarik serta terdapat juga pop up yang dapat muncul jika dibuka. Media Pop Up Book ini dikembangkan berdasarkan pada pembelajaran yang berpedoman pada Kurikulum 2013 atau tematik. Dengan dikembangkannya media pembelajaran tersebut diharapkan peserta didik akan mendapat pengalaman baru serta tertarik untuk mengikuti kegiatan pembelajaran menggunakan media pembelajaran yang berbeda dari biasanya.

C. Pengembangan

1) Pembuatan media Pop Up Book

Pada tahap pengembangan, peneliti membuat media pembelajaran Pop Up Book.

2) Validasi ahli media dan materi

Validator atau pakar ahli yang memvalidasi media dan yang memvalidasi materi dalam media Pop Up Book pada kelas IV Sekolah Dasar pada Tema VI Cita-citaku Subtema 1 Aku dan Cita-citaku Pembelajaran 2 merupakan dosen dari PGSD Universitas PGRI Semarang, yaitu Ikha Listyarini, S.Pd., M.Hum., Arfilia Wijayanti, S.Pd., M.Pd., Ari Widyaningrum, S.Pd., M.Pd dan Rofian, S.Pd., M.Pd. Berikut merupakan deskripsi hasil tahap pengembangan yang telah dilakukan oleh peneliti:

a) Penilaian ahli media

Tabel 4. Hasil Validasi Ahli Media

\begin{tabular}{cccc}
\hline No. & Ahli Media & Presentasi Keidealan & Kriteria \\
\hline 1 & Rofian, S.Pd.,M.Pd & $92,5 \%$ & Sangat Baik \\
\hline
\end{tabular}

Berdasarkan Tabel 4 maka dapat diperoleh hasil presentase keidealan penilaian ahli media sebesar 92,5\% sehingga media Pop Up Book termasuk dalam kriteria "sangat baik". Pada validasi ini terdapat saran perbaikan berupa penggantian bahan cover depan agar lebih tebal sehingga dapat tahan lama.

b) Penilaian Ahli Materi

Tabel 5. Hasil Validasi Ahli Materi

\begin{tabular}{cccc}
\hline No. & Ahli Materi & Presentasi Keidealan & Kriteria \\
\hline 1. & Ikha Listyarini, S.Pd., M.Hum. & $93,75 \%$ & Sangat Baik \\
2. & Arfilia Wijayanti, S.Pd., M.Pd. & $96,87 \%$ & Sangat Baik \\
3. & Ari Widyaningrum, S. Si., M.Pd. & $93,75 \%$ & Sangat Baik \\
\hline
\end{tabular}


Berdasarkan Tabel 5 maka dapat diperoleh hasil rata-rata presentase keidealan penilaian ahli materi sebesar 94,79\% sehingga media Pop Up Book termasuk dalam kriteria "sangat baik".

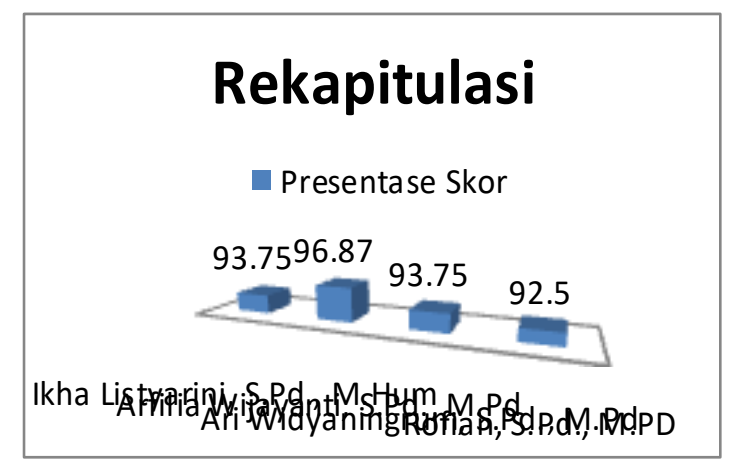

Berdasarkan diagram tersebut dapat disimpulkan bahwa hasil dari setiap penilaian dosen ahli mempunyai nilai yang besar. Selanjutnya empat presentase dari dosen tersebut dijumlah yang kemudian dibagi dengan skor maksimal presentasi dan diperoleh hasil sebesar 94,21\%. Dimana skor tersebut terletak pada interval 81\%-100\% dengan kategori "Baik Sekali" yang artinya bahwa media pembelajaran pop up book sangat layak digunakan untuk penelitian.

c) Hasil Respon Guru, Respon Siswa, dan Keberterimaan Media

Keberhasilan media yang dikembangkan berdasarkan dilakukannya uji coba lapangan sehingga media pembelajaran Pop Up Book dapat diterima dan dikatakan berhasil. Data mengenai respon guru, respon siswa dan keberterimaan media pada media ini dalam bentuk skala Likert. Uji coba lapangan awal dilakukan peneliti di kelas IV di SDN Wonokerto 01 Batang yang bertujuan untuk mengetahui respon guru kelas, respon siswa dan keberterimaan media. Sehingga diperoleh hasil sebagai berikut:

I. Hasil Respon Guru

Tabel 6. Hasil Respon Guru

\begin{tabular}{cccc}
\hline No. & Nama & Presentasi Keidealan & Kriteria \\
\hline 1. & Umi Khamidah, S.Pd & $92,85 \%$ & Sangat Baik \\
\hline
\end{tabular}

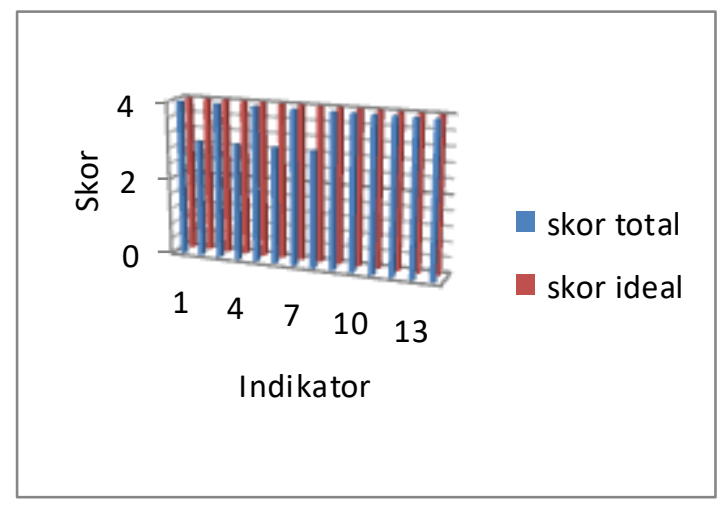

Berdasarkan Tabel 6 dan diagram 1 menunjukkan bahwa hasil analisis respon guru terhadap media Pop Up Book, diperoleh hasil sebesar 92,85\%. Sehingga media Pop Up Book termasuk dalam kategori "Sangat Baik". 
II. Hasil Respon siswa

Tabel 7. Hasil Respon Siswa

\begin{tabular}{cccc}
\hline No. & Kelas & Presentasi Keidealan & Kriteria \\
\hline 1. & IV & $90 \%$ & Sangat Baik \\
\hline
\end{tabular}

Berdasarkan Tabel 7 menunjukkan bahwa hasil analisis respon siswa terhadap media Pop Up Book yang dilakukan oleh kelas IV SDN Wonokerto 01 diperoleh hasil sebesar 90\%. Sehingga media Pop Up Book termasuk dalam kategori "Sangat Baik".

III. Hasil Keberterimaan Media

Tabel 8 Hasil Keberterimaan Media

\begin{tabular}{cccc}
\hline No. & Kelas & Presentasi Keidealan & Kriteria \\
\hline 1. & IV & $90 \%$ & Sangat Baik \\
\hline
\end{tabular}

Berdasarkan Tabel 8 menunjukkan bahwa hasil analisis keberterimaan media terhadap media Pop Up Book yang dilakukan oleh kelas IV SDN Wonokerto 01 diperoleh hasil sebesar 90\%. Sehingga media Pop Up Book termasuk dalam kategori "Sangat Baik".

d) Uji Coba

Pada tahap uji coba atau penerapan peneliti melakukan penelitian dengan mempraktikan media pembelajaran pop up book dalam pembelajaran di kelas IV SD Negeri Wonokerto 01 Batang. Peneliti menjelaskan materi Tema VI Cita-citaku Subtema 1 Aku dan cita-citaku Pembelajaran 2 menggunakan media pop up book. Setelah mencoba menggunakan media pop up book peneliti memberikan angket respon guru, respon siswa dan angket keberterimaan media kepada masingmasing siswa. Hasil angket respon guru, respon siswa dan keberterimaan akan dibahas dalam poin deskripsi uji keberterimaan media.

\section{KESIMPULAN}

Berdasakan hasil penelitian dan pengembangan media pembelajaran Pop Up Book dapat disimpulkan bahwa: 1) Dihasilkan produk media pembelajaran pop up book sebagai media pembelajaran tematik pada Tema VI Cita-citaku Subtema 1 Aku dan Cita-citaku Pembelajaran 2. Media yang berbahan dasar dari kertas ivory yang kemudian di desain untuk dijadikan pop up. Media ini mempunyai warna yang beragam dan gambar yang menarik. Media pop up ini praktis dan dapat dibawa kemana saja dengan mudah. Untuk melindungi bagian dalam media terdapat cover yang membungkus media pop up. Terdapat pop up yang dapat muncul saat membuka lembar, dan terdapat pop up yang harus ditarik lalu gambar akan muncul. 2) Media pop up book memiliki hasil nilai rata-rata ahli materi dan ahli media pembelajaran sebesar 94,21\%. Nilai tersebut berdasarkan rekapitulasi hasil penilaian ahli materi dan ahli media pembelajaran. Nilai tersebut berada pada interval 81\%-100\% yang termasuk pada kategori "Baik Sekali". Artinya media pop up book layak digunakan sebagai media pembelajaran Tema VI Cita-citaku Subtema 1 Aku dan Cita-citaku Pembelajaran 2. 3) Media pop up book mendapatkan respon guru sebesar 92,85\%. Nilai tersebut berdasarkan angket respon guru. Media pop up book mendapatkan respon siswa sebesar 99,45\%, nilai tersebut berdasarkan dari angket respon siswa. Selanjutnya media pop up book diterima sebagai media pembelajaran dengan mendapatkan skor sebesar $90 \%$, nilai tersebut berdasarkan dari angket keberterimaan media. Ketiga nilai tersebut terletak pada interval $81 \%-100 \%$ yang termasuk dalam kategori "Baik Sekali". Hal tersebut membuktikan bahwa media pop up book layak dan dapat diterima dengan baik oleh guru maupun oleh siswa untuk digunakan sebagai media pembelajaran tematik dikelas.

Berdasarkan hasil penelitian yang telah dilakukan, maka saran yang diberikan adalah: 1) Media pop up book dapat digunakan pada pembelajaran tematik maupun pembelajaran bukan tematik selama masih berhubungan dengan materi yang ada pada media pop up book. 2) Media pop up book dapat digunakan sebagai pengganti buku maupun gambar. 3) Dalam pembelajaran hendaknya menggunakan media pembelajaran, terutama pada materi yang susah dipahami siswa. Agar siswa mampu memahami materi dengan baik dan pembelajaran dapat berlangsung dengan menarik. 4) Penelitian dan pengembangan yang belum sempurna ini, diharapkan dilakukan penelitian pengembangan selanjutnya dikemudian hari guna menyempurnakan penelitian ini dan menjadi produk baru dalam penelitian 
pengembangan tentang media pembelajaran. 5) Pada penelitian selanjutnya diharapkan dapat menggandakan produk media pop up book lebih banyak. 6) Guru diharapkan dapat mengembangkan inovasi dan lebih kreatif dalam membuat media pembelajaran tematik yang baru dari pop up book dengan tema yang berbeda. 7) Tahap pembuatan produk media pop up book pada penelitian selanjutnya diharapkan dapat memperbanyak objek bagian pop up dalam media sehingga lebih menarik bagi siswa.

\section{DAFTAR PUSTAKA}

Arikunto, Suharsimi. 2010. Prosedur Penelitian. Jakarta: Bumi Aksara.

Asmara, Anjar Purba. 2015. Pengembangan Media Pembelajaran Berbasis Audio Visual tentang Pembuatan Koloid. Jurnal Ilmiah Didaktika Vol. 15 No. 2 Hal. 156-178. Tersedia Pada: https://jurnal.ar-raniry.ac.id/index.php/didaktika/article/view/578/481.

Azizan, Yoga Rifqi, Syamsul Sodiq. 2018. Pengembangan Media Pop Up Book dalam Pembelajaran Menulis Puisi Berbasis Psychowriting pada Siswa Kelas VIII D SMP Negeri 1 Srengat Kabupaten Blitar Tahun Pelajaran 2017/2018. Bapala Vol. 5 No.2 Hal. 1-6. http://jurnalmahasiswa.unesa.ac.id/index.php/bapala/issue/view/1443.

Haji, Sun. 2015. Pembelajaran Tematik yang Ideal di SD/MI. STITNU Al Hikmah Mojokerto Vol. III No. 1 Hal. 56-69. Tersedia Pada: https://www.researchgate.net/publication/307776596_PEMBELAJARAN_TEMATIK_YANG_IDEAL _DI_SDMI

Hartono, Rudi. 2013. Ragam Model mengajar yang Mudah Diterima Murid. Jogjakarta: DIVA Press.

Kadir dan Asrohah, Hanun.2014. Pembelajaran Tematik. Jakarta: Rajawali Pers.

Masturah, Elisa Diah Luh Putu Putrini Mahadewi, Alexander Hamonangan Simamora. 2018. Pengembangan Media Pembelajaran Pop-Up Book Pada Mata Pelajaran Ipa Kelas Iii Sekolah Dasar. Masturah (2018). Jurnal Jurusan Teknologi Pendidikan. Vol. 9 No. 2 Hal. 215-225. Tersedia Pada: https://ejournal.undiksha.ac.id/index.php/JEU/article/view/14728.

Sanaky, Hujair AH. 2013. Media Pembelajaran Interaktif-Inovatif. Yogyakarta: Kaukaba Dipantara.

Sholikhah, Aimatus, Alfi Laila, Samijo. 2017. Pengembangan Media Pop Up Book untuk Meningkatkan Kemampuan Menulis Kreatif pada Mata Pelajaran Bahasa Indonesia Materi Menulis Karangan Kelas V SDN Rowoharjo Tahun Ajaran 2016/2017. Simki-Pedagogia Vol. 01 No. 08 Hal. 1-12. Tersedia Pada: http://simki.unpkediri.ac.id/mahasiswa/file_artikel/2017/5ee12721ce5cc0d9ddc2f1e33ed818c3 .pdf.

Sugiyono. 2017. Metode Penelitian Pendidikan. Bandung: Alfabeta.

Wahyuni, Hermin Tri, Punaji Setyosari, Dedi Kuswandi . 2016. Implementasi Pembelajaran Tematik Kelas 1 SD. Edcomtech Vol. 1, No. 2, Hal. 129-136. Tersedia Pada: http://journal2.um.ac.id/index.php/edcomtech/article/view/1799. 